\title{
Diphtheria Outbreak in Amerindian Communities, Wonken, Venezuela, 2016-2017
}

\section{Adriana Lodeiro-Colatosti, Udo Reischl, Thomas Holzmann, Carlos E. Hernández-Pereira, Alejandro Rísquez, Alberto E. Paniz-Mondolfi}

In February 2017, a diphtheria outbreak occurred among Amerindians of the Pemón ethnic group in Wonken, Venezuela. A field investigation revealed $\approx 10$ cases; clinical presentation did not include cutaneous or neurologic signs or symptoms. To prevent future outbreaks in Venezuela, Amerindian communities need better access to vaccination and healthcare.

$\mathrm{D}$ iphtheria is a contagious acute bacterial infection caused by toxin-producing, gram-positive Corynebacterium diphtheriae and other Corynebacteria ssp., such as Corynebacterium ulcerans $(1,2)$. Humans are a known reservoir, but bacteria can also be isolated from horses and cats. Transmission occurs primarily through contact with airborne respiratory secretions or exudation from infected skin lesions (3-5). The incidence of diphtheria in the Western Hemisphere has decreased dramatically over the past few decades, although the disease has remained endemic in some developing countries around the globe. Diphtheria was eradicated in Venezuela 25 years ago; the last reported case occurred in $1992(6)$.

However, in November 2016, the International Health Regulations National Focal Point of Venezuela updated the Pan American Health Organization and World Health Organization about diphtheria in the country, reporting that 16 of 24 federal agencies had reported 183 suspected cases of the disease during September-November 2016 (6). During

Author affiliations: Instituto de Salud Pública del Estado Bolívar, Bolívar, Venezuela (A. Lodeiro-Colatosti); Infectious Diseases Research Incubator, Barquisimeto, Venezuela (A. Lodeiro-Colatosti, C.E. Hernández-Pereira); Zoonosis and Emerging Pathogens Regional Collaborative Network, Barquisimeto (A. Lodeiro-Colatosti, C.E. Hernández-Pereira); University Hospital of Regensburg, Regensburg, Germany (U. Reischl, T. Holzmann); Universidad Centroccidental Lisandro Alvarado, Barquisimeto (C.E. HernándezPereira); Universidad Central de Venezuela, Caracas, Venezuela (A. Rísquez); Instituto de Investigaciones Biomédicas IDB, Cabudare, Venezuela (A.E. Paniz-Mondolfi); Instituto Venezolano de los Seguros Sociales, Caracas (A.E. Paniz-Mondolfi)

DOI: https://doi.org/10.3201/eid2407.171712 weeks 1-49 of 2017, suspected and confirmed diphtheria cases were reported in 4 countries in the Americas: Brazil (4 cases), the Dominican Republic (3 cases), Haiti (152 probable cases), and Venezuela (227 cases) (7).

\section{The Study}

In February 2017, a cluster of $\approx 10$ cases of an illness characterized by swollen neck occurring in 7 children and 3 adults (including 2 deaths) was reported in 3 Amerindian communities (Urimpatá $\left[5.128429^{\circ} \mathrm{N}\right.$, $-61.380956^{\circ} \mathrm{E}$ ]; Damasko [5.127997 ${ }^{\circ} \mathrm{N},-61.504152^{\circ} \mathrm{E}$ ]; Atanao $\left.\left[5.128429^{\circ} \mathrm{N},-61.380956^{\circ} \mathrm{E}\right]\right)$ of the Great Savannah in Bolivar, Venezuela (Table). These settlements, which are part of the greater Weiyekupotá community, are home to the seminomadic populations of the Pemón aboriginals, who migrate for long periods to perform agricultural, hunting, fishing, and mining activities, with regular return visits to their home villages. Reaching these isolated communities can only be achieved by river navigation or small aircraft. Access to healthcare for this population is limited ( $\approx 2$-day walk to closest hospital); according to reports from the Ministry of Health, the estimated diphtheria vaccination coverage rates during the first half of 2016 were $<24 \%$. This cluster of diphtheria cases prompted an epidemiologic investigation in the affected communities.

In Urimpatá, a 31-year-old Amerindian man (casepatient 1) who had recently returned home from a gold mining camp in Apoipó $\left(4.744573^{\circ} \mathrm{N},-61.477692^{\circ} \mathrm{E}\right)$ and 2 members of his household, his 4-year-old daughter (case-patient 2) and 9-year-old niece (case-patient 3 ), sought treatment for symptoms they had been experiencing for over a week. All 3 exhibited classic signs of diphtheria (Figure 1; Table) and did not have cutaneous lesions or neurologic signs or symptoms.

Pharyngeal samples from the index case-patient were collected on swabs and applied to glass slides, which were submitted for real-time PCR testing, as previously described (8). Compared with collecting the sample by scraping the dried sample from the glass slide, collecting the sample by rubbing the slide with a moist swab (wetted with phosphate-buffered saline) led to $\approx 100$-fold higher yields of DNA in subsequent PCR assays. Samples were positive for $C$. diphtheriae toxin gene (tox) by real-time reverse transcription PCR; we observed cycle thresholds of $\approx 30$ 
Table. Demographics and clinical characteristics of 10 Amerindians with suspected diphtheria cases, Wonken, Venezuela, 2017* Casepatient

\begin{tabular}{|c|c|c|c|c|c|c|}
\hline no. & Age, $y /$ sex & Location† & Signs and symptoms & Duration & Treatment & Outcome \\
\hline 1 & $\begin{array}{l}31 / \mathrm{M} \\
\text { returning } \\
\text { miner }\end{array}$ & Urimpatá & $\begin{array}{c}\text { Hyperthermia; dysphagia; } \\
\text { odynophagia; dysphonia; gray } \\
\text { adherent membranes; massive } \\
\text { cervical lymphadenopathy }\end{array}$ & $9 \mathrm{~d}$ & $\begin{array}{l}\text { Azithromycin (500 mg, } 2 \times / \mathrm{d} \text { for } \\
10 \mathrm{~d}), 7-\mathrm{d} \text { cycle } \\
\text { ampicillin/sulbactam, penicillin } \mathrm{G} \\
\text { benzathine ( } 1.2 \text { million units, IM, } \\
1 \text { dose), adult Td to contacts }\end{array}$ & Survived \\
\hline 2 & $\begin{array}{l}4 / F \\
\text { household } \\
\text { contact of } \\
\text { case- } \\
\text { patient } 1\end{array}$ & Urimpatá & $\begin{array}{l}\text { Dysphagia; odynophagia; } \\
\text { hemoptysis; fever; gray adherent } \\
\text { membrane formation; cervical } \\
\text { lymphadenopathy }\end{array}$ & $7 \mathrm{~d}$ & $\begin{array}{l}\text { Azithromycin }(10 \mathrm{mg} / \mathrm{kg}, 1 \times / \mathrm{d} \text { for } \\
7 \mathrm{~d}) \text {, cefotaxime/clarithromycin } \\
\text { at admission, Tdap vaccination }\end{array}$ & $\begin{array}{l}\text { Survived, } \\
\text { admitted to } \\
\text { reference } \\
\text { hospital }\end{array}$ \\
\hline 3 & $\begin{array}{l}9 / F \\
\text { household } \\
\text { contact of } \\
\text { case- }\end{array}$ & Urimpatá & $\begin{array}{l}\text { Abrupt onset of odynophagia; barking } \\
\text { cough; dysphonia; stridor and gray } \\
\text { adherent pseudomembranes } \\
\text { covering tonsils, uvula, and pharynx }\end{array}$ & $7 d$ & $\begin{array}{c}\text { Azithromycin }(10 \mathrm{mg} / \mathrm{kg}, 1 \times / \mathrm{d}, 7 \\
\mathrm{d}) \text {, penicillin } \mathrm{G} \text { benzathine }(0.6 \\
\text { million units, IM, } 1 \text { dose }) \text {, Tdap } \\
\text { vaccination }\end{array}$ & Survived \\
\hline
\end{tabular}

\begin{tabular}{|c|c|c|c|c|c|c|}
\hline 4 & $14 / F$ & Atanao & $\begin{array}{l}\text { Fever; dysphonia; dysphagia; } \\
\text { odynophagia }\end{array}$ & $\approx 1 \mathrm{wk}$ & No data & Died \\
\hline 5 & $4 / \mathrm{M}$ & Atanao & $\begin{array}{l}\text { Dysphagia; odynophagia; dysphonia; } \\
\text { hyporexia }\end{array}$ & $\approx 1 \mathrm{wk}$ & No data & Died \\
\hline 6 & $9 / F$ & Urimpatá & $\begin{array}{c}\text { Odynophagia; barking cough; } \\
\text { dysphonia; stridor and gray } \\
\text { pseudomembrane covering tonsils, } \\
\text { uvula, and pharynx }\end{array}$ & $\approx 1 \mathrm{wk}$ & $\begin{array}{l}\text { Azithromycin }(10 \mathrm{mg} / \mathrm{kg}, 1 \times / \mathrm{d}, 7 \\
\mathrm{d}) \text {, penicillin } \mathrm{G} \text { benzathine }(0.6 \\
\text { million units, IM, } 1 \text { dose }) \text {, Tdap } \\
\text { vaccination }\end{array}$ & Survived \\
\hline 7 & $9 / F$ & Damasko & $\begin{array}{l}\text { Dysphagia; odynophagia; dysphonia; } \\
\text { fever; gray pseudomembrane } \\
\text { covering tonsils, uvula, and pharynx }\end{array}$ & $\approx 1 \mathrm{wk}$ & $\begin{array}{c}\text { Azithromycin }(10 \mathrm{mg} / \mathrm{kg}, 1 \times / \mathrm{d} \text { for } \\
7 \mathrm{~d}) \text {, penicillin } \mathrm{G} \text { benzathine }(0.6 \\
\text { million units, IM, } 1 \text { dose), Tdap } \\
\text { vaccination }\end{array}$ & Survived \\
\hline 8 & $13 / \mathrm{F}$ & Damasko & $\begin{array}{l}\text { Odynophagia; fever; small grayish } \\
\text { membranes admixed with vesicles } \\
\text { covering pharynx }\end{array}$ & $\approx 1 \mathrm{wk}$ & $\begin{array}{c}\text { Azithromycin }(10 \mathrm{mg} / \mathrm{kg}, 1 \times / \mathrm{d} \text { for } \\
7 \mathrm{~d}) \text {, penicillin } \mathrm{G} \text { benzathine }(0.6 \\
\text { million units, IM, } 1 \text { dose), Tdap } \\
\text { vaccination }\end{array}$ & Survived \\
\hline 9 & Unknown & $\begin{array}{l}\text { Atanao, in } \\
\text { transit to } \\
\text { Vista Alegre } \\
\text { community }\end{array}$ & $\begin{array}{l}\text { Reported as signs and symptoms } \\
\text { suggestive of diphtheria }\end{array}$ & Unknown & No data & Unknown \\
\hline 10 & Unknown & $\begin{array}{l}\text { Atanao, in } \\
\text { transit to } \\
\text { Vista Alegre } \\
\text { community }\end{array}$ & $\begin{array}{l}\text { Reported as signs and symptoms } \\
\text { suggestive of diphtheria }\end{array}$ & Unknown & No data & Unknown \\
\hline
\end{tabular}

and the characteristic melting temperature by LightCycler hybridization probe (Sigma-Aldrich, St. Louis, MO, USA) melting curve analysis.

Persons with suspected diphtheria were given penicillin $\mathrm{G}$ benzathine and azithromycin (Table). Because erythromycin and penicillin $\mathrm{G}$ procaine were not available and to broaden antimicrobial coverage, we additionally gave case-patient 1 a 7 -day course of ampicillin/sulbactam and case-patient 2 cefotaxime/clarithromycin. Case-patient 2 was transferred to the nearest hospital for further assistance. None of the case-patients identified in this outbreak were given diphtheria antitoxin because of supply shortages nationwide. A few days before case-patients 1-3 sought treatment, 2 deaths were reported in Atanao in persons exhibiting the same symptoms: a 14-year-old girl (died in the community) and 4-year-old boy (transferred to Boa Vista,
Brazil, and died later) (Table). Our team could not reach the rest of the case-patients with suspected diphtheria in distant mines and villages, but local personnel registered cases in adult miners in Atanao. None of these case-patients had been previously immunized. All 41 Amerindians examined by the investigation team and their contacts from 3 different villages received toxoid immunization.

\section{Conclusions}

Although diphtheria is declining or has been eliminated from many countries because of high and widespread immunization coverage, the disease remains endemic to some developing countries, especially in regions under extreme poverty and low vaccine coverage (3). Over the past 4 years, Venezuela has faced a sharp reduction in oil revenue and undergone economic and political developments 

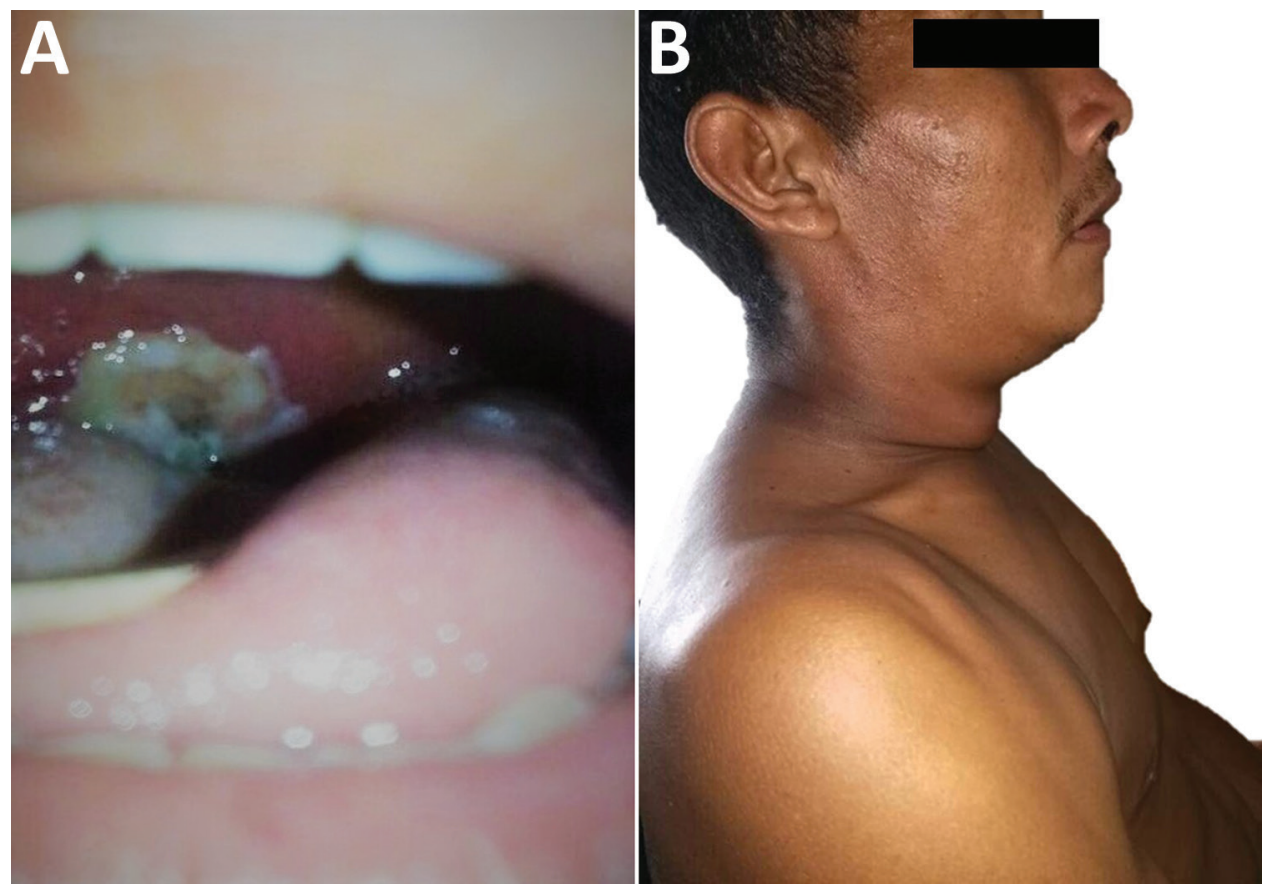

Figure 1. Physical characteristics of 31-yearold Amerindian male index case-patient with diphtheria, Wonken, Venezuela, 2017. A) Firmly adherent gray-white pseudomembrane in pharynx. B) Typical bull-like neck swelling with massive cervical adenopathies.

that have led to high inflation, impoverishment, and scarcity of basic resources largely affecting the public health infrastructure, resulting in long-term shortages of essential medicines and medical supplies, including vaccines for universal immunization programs and the immunization of specific risk groups against specific diseases (9). In addition, job shortages have pushed many locals into the practice of informal economy, food speculation, and, particularly, illegal gold mining.

The state of Bolivar is the largest federal entity in the country and the richest in mineral deposits. Legal and illegal mining activity is ongoing and rapidly growing, especially since the government announced the uncontrolled opening of the mining arch of the Orinoco River in 2011. This situation has led to an unprecedented increase in vectorborne disease transmission in these areas (8). From week 1 in 2016 through week 48 in 2017, a total of 609 suspected cases were reported in Venezuela, 227 of which were laboratory confirmed, with a case-fatality rate (CFR) of $15.5 \%$ (7). As of week 24 in 2017, a total of $282(63 \%)$ cases were reported from Bolivar (Figure 2, panels A, B), with most occurring in the highly populated municipalities of Heres and Sifontes (10). However, to the best of our knowledge, diphtheria cases among the isolated Amerindian communities of the Savannah Plateau we examined has not been reported elsewhere.

Diphtheria is primarily controlled by vaccination and ensuring optimal herd immunity through high immunization coverage (3). The occurrence of diphtheria outbreaks reflects inadequate vaccination coverage. This outbreak was probably the consequence of the reintroduction of previously eradicated diseases by infected migrants traveling through mining districts and low vaccination rates.

Although calculated as $15.5 \%$, the CFR of this epidemic cannot be accurately estimated because of the geographic isolation and elusive nature of most Amerindian communities. However, the CFR is expected to be higher because of the low vaccination rates and complete absence of effective diphtheria treatments in most of the region.

This outbreak highlights 2 issues: the unknown epidemiologic effect of diphtheria on isolated, immunologically naive Amerindian tribes in Venezuela and the difficulty of diagnosing diphtheria when clinicians are unfamiliar with the disease, tribe members have limited access to healthcare, and doctors lack treatment and laboratory facilities. Of note, the diagnosis of 1 diphtheria case was made by using pharyngeal samples applied to glass slides that were later processed by molecular methods; the enhanced DNA detection seen by using wet swabs is a valuable observation, potentially making diagnosis more accessible for resource-poor communities.

Reports of diphtheria affecting other aboriginal communities in Venezuela, such as the Kariña population (Gran Kashaama, Guanipa Plateau, Anzoategui), indicate that further investigation is necessary to elucidate the true extent of diphtheria. The public health challenge of improving the provision of preventive services and access to medical care for the isolated and underserved communities in Bolivar is needed to prevent future diphtheria outbreaks.

This study was supported in part by the Scottish Funding Council Global Challenges Research Fund (SFC/AN/12/2017). 


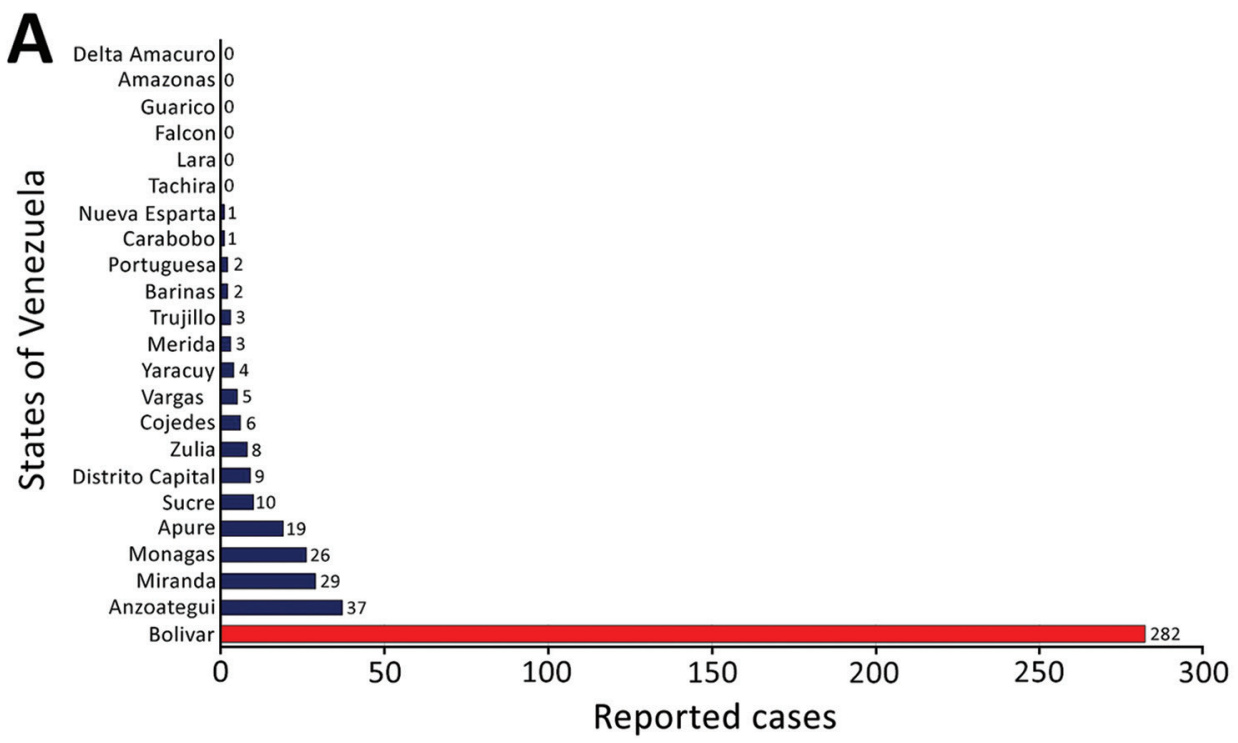

Figure 2. Suspected and confirmed diphtheria cases and deaths, by state, Venezuela, 2016-2017. The highest number of cases occurred in the state where Amerindians reside (Bolivar, red). A) Number of suspected cases of diphtheria reported from week 28 of 2016 through week 24 of 2017 , by state. B) Location of confirmed cases and deaths, Venezuela, 2017. The affected Amerindian communities reside in the area within the dotted line.

Map obtained from d-maps (http://d-maps.com/carte. php?num car=4080\&lang=es).

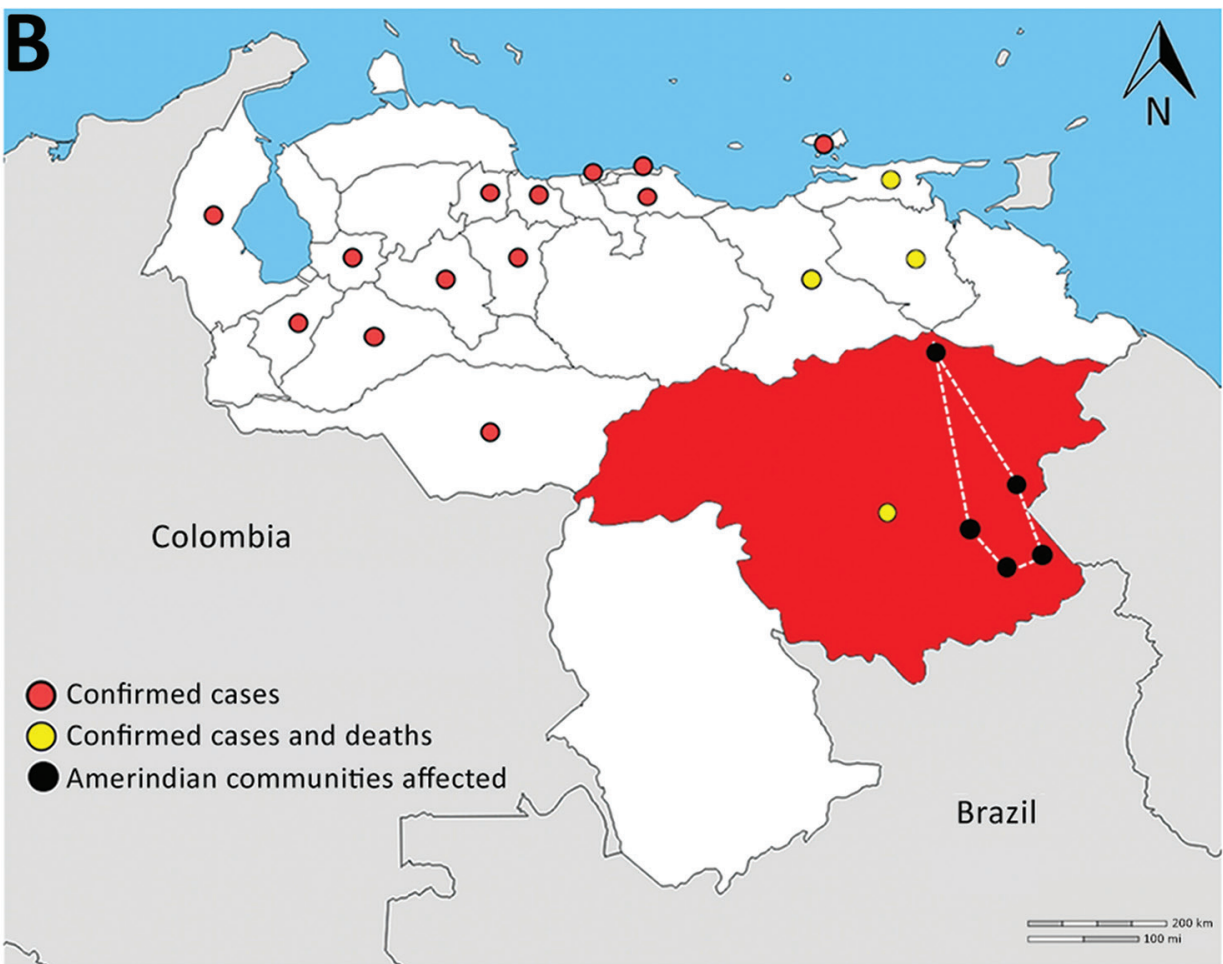

\section{About the Author}

Dr. Lodeiro-Colatosti is an attending physician and clinical researcher at the Infectious Diseases Research Incubator and the Zoonosis and Emerging Pathogens regional collaborative network in Barquisimeto, Venezuela. She also serves as medical staff in the Amerindian community when she resides in Wonken, Venezuela. Dr. Lodeiro-Colatosti has devoted her career to investigating the clinical tropical diseases.

\section{References}

1. Bonmarin I, Guiso N, Le Flèche-Matéos A, Patey O, Grimont Patrick AD, Levy-Bruhl D. Diphtheria: a zoonotic disease in France? Vaccine. 2009;27:4196-200. http://dx.doi.org/ 10.1016/j.vaccine.2009.04.048

2. Wagner KS, White JM, Crowcroft NS, De Martin S, Mann G, Efstratiou A. Diphtheria in the United Kingdom, 1986-2008: the increasing role of Corynebacterium ulcerans. Epidemiol Infect. 2010;138:1519-30. http://dx.doi.org/10.1017/ S0950268810001895 
3. MacGregor RR. Corynebacterium diphtheriae. In: Mandell, Douglas, and Bennett's Principles and practice of infectious diseases, 7th ed. Philadelphia: Churchill Livingstone Elsevier; 2010. p. 2687-93.

4. Hall AJ, Cassiday PK, Bernard KA, Bolt F, Steigerwalt AG, Bixler D, et al. Novel Corynebacterium diphtheriae in domestic cats. Emerg Infect Dis. 2010;16:688-91. http://dx.doi.org/10.3201/ eid1604.091107

5. Dixon B. Dangerous horseplay. Lancet Infect Dis. 2010;10:741. http://dx.doi.org/10.1016/S1473-3099(10)70230-9

6. Irish College of General Practitioners. IHR alert: extensive outbreak of diphtheria in Venezuela. 2016 Dec 6 [cited 2017 Oct 10]. https://www.icgp.ie/go/library/public_health_alerts/ 4745104B-0F5C-F480-148C74944F931F3D.html

7. Pan American Health Organization; World Health Organization. Epidemiological update: diphtheria. Diphtheria in the Americas-summary of the situation. 2018 Feb 28 [cited 2018 Mar 11]. http://www.paho.org/hq/index.php?option=com content\&view $=$ article\&id=14164\%3A28-february-2018diphtheria-epidemiological-update $\&$ catid $=2103 \% 3$ Arecentepidemiological-alerts-updates\&Itemid $=42346 \&$ lang $=$ en
8. Sing A, Berger A, Schneider-Brachert W, Holzmann T, Reischl U. Rapid detection and molecular differentiation of toxigenic Corynebacterium diphtheriae and Corynebacterium ulcerans strains by LightCycler PCR. J Clin Microbiol. 2011;49:2485-9. http://dx.doi.org/10.1128/JCM.00452-11

9. Fraser B. Data reveal state of Venezuelan health system. Lancet. 2017;389:2095. http://dx.doi.org/10.1016/ S0140-6736(17)31435-6

10. Pan American Health Organization; World Health Organization. Epidemiological update: diphtheria. Diphtheria in the Americassummary of the situation. 2017 Aug 22 [cited 2017 Oct 10]. http://new.paho.org/hq/index.php?option=com_docman\&task= doc_view\&Itemid $=270 \&$ gid $=41629 \&$ lang $=$ en

Address for correspondence: Alberto E. Paniz-Mondolfi, Clínica IDB Cabudare, Instituto de Investigaciones Biomédicas IDB, Department of Tropical Medicine and Infectious Diseases, Av. Intercomunal Barquisimeto-Cabudare, Urb. Los Rastrojos, Cabudare Estado Lara 3023, Venezuela; email: albertopaniz@yahoo.com

\section{November 2016: Bacterial Pathogens}

- Transmission of Babesia microti Parasites by Solid Organ Transplantation

- Immune Responses to Invasive Group B Streptococcal Disease in Adults
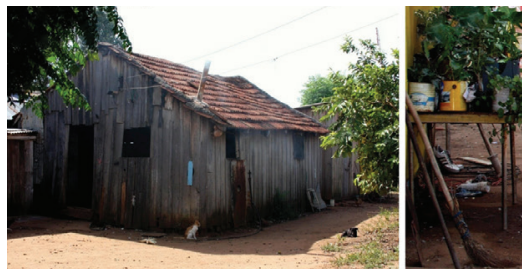

- Ambulatory Pediatric Surveillance of Hand, Foot and Mouth Disease as Signal of an Outbreak of Coxsackievirus A6 Infections, France, 2014-2015

- Increased Hospitalization for Neuropathies as Indicators of Zika Virus Infection, according to Health Information System Data, Brazil

- Global Escherichia coli Sequence Type 131 Clade with bla CTX-M-27 $_{\text {Gene }}$

- Multidrug-Resistant Corynebacterium striatum Associated with Increased Use of Parenteral Antimicrobial Drugs

- Risk Factors for Middle East Respiratory Syndrome Coronavirus Infection among Healthcare Personnel

- Epidemiology of La Crosse Virus Emergence, Appalachian Region, United States

- Reassortant Eurasian Avian-Like Influenza A(H1N1) Virus from a Severely III Child, Hunan Province, China, 2015

- Serotype IV Sequence Type 468 Group B Streptococcus Neonatal Invasive Disease, Minnesota, USA
- Capsular Switching and Other Large-Scale Recombination Events in Invasive Sequence Type 1 Group B Streptococcus

- Changing Pattern of Chlamydia trachomatis Strains in Lymphogranuloma Venereum Outbreak, France, 2010-2015

- ESBL-Producing and Macrolide-Resistant Shigella sonnei Infections among Men Who Have Sex with Men, England, 2015

- Early Growth and Neurologic Outcomes of Infants with Probable Congenital Zika Virus Syndrome

- Severe Fever with Thrombocytopenia Syndrome Complicated by Co-infection with Spotted Fever Group Rickettsiae, China

- Guinea Worm (Dracunculus medinensis) Infection in a Wild-Caught Frog, Chad

- Dog-Mediated Human Rabies Death, Haiti, 2016

- Staphylococcus aureus Colonization and Long-Term Risk for Death, United States

- Group B Streptococcus Serotype III Sequence Type 283 Bacteremia Associated with Consumption of Raw Fish, Singapore

- Group B Streptococcus Sequence Type 283 Disease Linked to Consumption of Raw Fish, Singapore

- Novel Levofloxacin-Resistant Multidrug-Resistant Streptococcus pneumoniae Serotype 11A Isolate, South Korea 